\title{
Chasu Euphemisms: An Ethnolinguistic Descriptive
}

\section{Account}

\author{
Erasmus Akiley Msuya (Corresponding author) \\ Department of Foreign Languages and Linguistics, University of Dar es Salaam \\ Tanzania \\ Tel: 255-756-537-686Ｅ-mail: msuyaerasmus@gmail.com
}

Received: May 13, 2017 Accepted: June 8, 2017 Published: September 5, 2017

doi:10.5296/ijch.v4i2.11808 URL: https://doi.org/10.5296/ijch.v4i2.11808

\begin{abstract}
The current study is an ethnographic descriptive account of use of euphuisms among the Chasu speaking community in their attempts to avoid impolite words. The study was conducted in Mwanga district, Kilimanjaro Region, in a remote rural ward known as Ngujini. 20 elderly people (13 men and 7 women) took part in the study, having been purposively sampled to be key informants. This was complimented by the researcher's introspection since he belongs to the same speech community as a native speaker. Data were gathered through spontaneous elicitation and were sound-recorded and later transcribed and then classified into their respective categories. The categories in focus were reference to sexual and excretory organs, reference to sexual and excretory processes, references to diseases and deaths and reference to pregnancy, births and deaths. The findings indicated that euphemisms referring to sexual activity were most dominant and picturesque while those referring to burial were the fewest. Most euphemisms were semantic extensions of existing Chasu words while a few were borrowings from other languages, notably Kiswahili. It has been concluded that Chasu people have crafty way of communicating whatever is unpleasant or impolite but also there are times their euphemistic expressions had attitudinal overtones leading to some pejorative expressions.
\end{abstract}

Keywords: Chasu, Ethnolinguistics, Euphemism, Dysphemism

\section{Introduction}

Language use within the framework of cultural beliefs is one of the areas of keen interests to sociolinguists and ethnographers. Among the areas of interest is avoidance of some words that are stigmatized as bad, impolite and rude-dubbed taboo words- with ones that are viewed 
as polite or politically correct. For Williams (1975 cited in Nyakoe et al. 2012), these substitute terms are called euphemisms and they are created when a taboo is abandoned and people have to find another linguistic form or expression to fill a gap. Bobb (1985 in Nyakoe et al. 2012) cites Epstein's justification for use of euphemisms asserting that there are times when a spade cannot be called a spade, which is why euphemistic expressions are used in presenting a situation, a person or an object in a more agreeable, more reassuring or politer light than would be afforded by the hard glare of reality or by crude, direct definition.

In quest for linguistic craftsmanship by speech communities to seek euphemistic expression, a number of scholars have carried out empirical studies some of which are reviewed here.

\subsection{On Death and Burial}

In East Africa, Nyakoe et al. (2012) studied conceptualization of metaphor of death in the use of euphemisms as a journey and as rest among the EkeGusii people of Kenya. The findings indicated that such conceptualization of death had religious undertones. Among examples of death as a journey are gokora orogendo ('to finish the journey'), korangeriwa na Omonene ('to be called/summoned by God'), kongong'anya ('to migrate') and aagenda ('He/she has gone').

In Asian and oriental cultures, there have also been studies on use of euphemisms. Galal (2014), for example, made an investigative comparison of the conceptualization of death euphemism in English and Arabic using the conceptual metaphor theory by Lackoff and Johnson (1980, 2003). He made a collection of 192 and 250 euphemistic expressions in Arabic and English, respectively. He found that both languages tended to use 10 strikingly similar complex metaphors to mitigate the effect of death and that the two languages tended to avoid mentioning death directly. Nonetheless, they differed as regards the emphasis, details and range of complex metaphor. For Arabic, for instance, a dead person envisaged as existing in a 'better' situation in terms being favoured by Allah as in '? ista?bhara i-laahu bih ("Allah favoured him'). Similarly, in English a dead person is said to have gone 'to a rest place', or to 'a better country'.

Among the Ndebele, Ndlovu (2011) analysed the influence of taboo words and euphemisms on language change, arguing that the presence of taboo words and euphemisms in Ndebele often results in changes in the meaning of words. He observed that changes that occur on the meaning of such words were often a result of the Ndebele people's perception of the referred subjects. Thus it is argued that language change can be influenced by the culture of a people. As a result, the affected words may be extended; that is, broadening the meaning, or the meaning may be narrowed. Words may also become unfavorable and fall off. The subjects of death and sexuality were used to demonstrate the changes in meanings of words.

\subsection{On Sexuality}

In South Africa, in the realm of sexuality, Cain (2000) explored language use by Xhosa speaking men and women and how such use if affected by an individual's level of politeness and need to protect one's face during sexual communication. The researcher conducted interviews to 17 men and 15 women in a township in Cape Town during which the 
respondents were asked to free-list words that are used to describe sexual anatomy and sexual acts. The results revealed that terms deemed to be most polite were euphemisms (in Xhosa), followed by terms borrowed from English. Examples for euphemistic expressions for sexual anatomy included those referring to male genitalia such as amasende ('genitals'), iketile ('kettle'), ibitsholoza ('snake winds up'), ubhuti ('brother') and istimbi ('iron'). There were also terms for female genitalia such as ikuku ('fat cake'), nosisi ('sister'), iswele ('onion'), ikomozakatata ('my father's cows'), and amalebe ('labium'). As for the sexual act terms used were like ukulana ('to sleep with'), ukutyana ('to eat each other'), ukuphana ('give'), ukidlala ('to play'), bhalana ('to write') and ukubhojabhojana ('toss and turn').

In Zimbabwe, Chabata and Mavhu (2005) examined the challenges facing lexicographers in defining offensive head-words in monolingual dictionary. They cited a few examples of offensive words in Shona such as mboro ('penis'), beche ('vagina'), chindori ('clitoris'), jende ('testacle'), mukosho ('anus'), mama (defacate) and tunda ('ejaculate/urinate'). One of the strategies for lexicographer was use of euphemistic expressions such as urete for sperm instead of explicit term uronyo, chirombo ('a huge creature') mbona usiku ('something that sees at night') for penis; as for vagina terms like sikarudzi ('one that creates a family'), or mukana ('a passage').

Fakuade et al (n.d.) made an overall classification of linguistic taboos among the Igbo in Nigeria into five categories, namely: morality-related linguistic taboos, veneration-related linguistic taboos, decorum-related linguistic taboos, religion-related linguistic taboos and fear-related linguistic taboos. They noted that veneration- and decorum-related taboos have euphemisms. Among the morality related euphemisms are: ihero o jiri buru nwoke ("what makes him male') referring to penis, abuba ('feather') for pubic hair and ihu onwa ('seeing the moon') for menstruation. As for veneration-related taboo words, examples of euphemistic expressions are eze (his royal highness) for king's personal name, Loolo ('her royal highness') for king's wife personal name and oriaku/odoziaku ('Mrs') for personal name of a married woman.

Greene's (2000) study sought to determine the differences in the use of euphemisms and taboo terms on the topics of sex and death by speakers of Russian and English. The survey instrument used was an opinion survey. The results indicate that the formality of a situation plays a greater role than gender when it comes to word choice and perceived offensiveness.

\subsection{On Socio-political Relations}

The Oromo speaking people in Ethiopia, observes Mbaya (2002), have euphemistic expressions as avoidance of mentioning the names of persons who are relations by marriage. For example, wives tend to use '-isin' (literally meaning 'you'), or '-isan' (meaning 'they'), jaarsa ko ('my husband'), warra ko ('head of house') or abbaa ('father of +name of the child'). Alternatively, they refer to their husbands in terms of their physical or character traits such as Abbaa cabsaa ('one who breaks his enemies'), Abbaa Dungumaa ('the truthful one') or Abbaa kaabu ('the gap toothed one').

Fernandez (2014) explored the way euphemisms are used by politicians from Norfolk and 
Suffolk both at word and sentence level using a sample of the regional newspaper Eastern Daily Press, published in Norwich (UK). He found that euphemisms play an important role in the self-promotion of regional politicians, who employ euphemism - mostly by understatement, litotes and under-specification - for a variety of purposes, namely sensitivity to audience concerns, avoidance of expressions that can be perceived to marginalize socially disadvantaged groups, polite criticism and mitigation of unsettling topics.

Oyeka (2015) examined various categories of taboo words' avoidances, the reason(s) behind their avoidance, and the strategies involved when the concepts referenced in such words or expressions must be employed. They collected 150 taboo words/expressions through elicitation by oral interviews from 200 Igbo native speakers. Findings indicated that the open usage avoidance of the words/expressions in question was conditioned by cultural and religious norms of the society and that euphemisms were mostly used as replacements for the avoided lexemes in certain contexts.

Usfiroh's (2014) study was on euphemistic expressions used by President Barack Obama in 2012 inaugural address. The study used a qualitative approach to analyze the data in form of transcript that contained euphemistic expression used by Obama. The findings showed that Obama used several types of euphemism: 2 compounding, 8 implication, 23 metaphor, 8 metonym, and 2 reversal.

From the literature survey above, one notes two things: one, studies have been too focused to one social event e.g. death, sexual taboos, and political speech on a single speech event. This diminishes room for comparability between or within case studies. Secondly, in East African region in general and in Tanzania in particular very little has been done in this area. The current study is an endeavor to contribute to that knowledge gap.

\section{Materials and Methods}

The study was conducted in Kisangara Juu, Ngujini, which a remote Chasu speaking ward located in Mwanga district in Kilimanjaro region, Tanzania. The choice of the village is justified by presence of elderly people known to the researcher the willingness and establishment of rapport of whom was important to access of data to the topic of this nature which calls for cultural sensitivity. The study thus involved 20 elderly, 13 men and 7 women. They were asked to spontaneously say what the label of substitute of any of the tabooed words irrespective of which category. The respondents were sound-recorded during the conversation. Then the speech events were played back and labels were identified and isolated by being transcribed. They were then assigned their respective categories and given description both by the researcher (using introspection since he is a native speaker of the language and the descriptions were vetted for accuracy by learned speakers of the language who were retirees in the village.

\section{Findings}

The findings are organised into four thematic categories regarding taboo words and their substituting euphemisms. These are sexual organs and processes, excretory organs and processes, diseases, and those referring to pregnancy, births and deaths. 


\subsection{Referring to Sexual and Excretory Organs}

Taboo words referring to sexual and excretory organs and their euphemisms. These are as described below.

3.1.1 Kidodo: This is a male sexual organ (penis) and it has the following euphemisms:

a) Kipunde: this literally means 'a smoking pipe' and is has been so labelled since the Chasu people believe male genital resembles a smoking pipe

b) Kighothi: this literally translates as 'manhood'. It reflects the organ's functionality and that it belongs to a mole gender. In that sense loosing manhood means also being sexually dysfunctional. It is an abstract form of mghothi (i.e "an elder) denoting the respect the part of body is accorded.

c) Kitala:- this literally means 'kings' palace' and is used more like an argot such that those that are young do not understand. It is usually used when one has forgotten to zip up his trousers or has put on a pyjama that leaves part of his sexual organ exposed. It is also used to refer to sexual organ when talking about diseases that have attached genitals.

d) Tuhu:- This literary means 'nakedness' and is used to refer to a sexual organ of a male child. It may also be used to infantilize someone or belittle him while referring to his sexual organ.

3.1.2 Kishi, a dysphemism for a female genital, this is the word that is held as a real sexual taboo and uttering it 'as is' is viewed as highest level of savagery. It has the following substitutions.

a) Tumbatu: literally meaning 'tobacco', the term is used as a counterpart of a male 'Kipunde' to show its complementarity with it. It is used in connection to sexual relations particularly in the woman's power to attract and keep a man in a relationship or even lure him away into infidelity. An interesting connection with kipunde (literally 'a smoking pipe') and this word (literally 'tobacco') sends powerful signal of the two being in inseparable mutuality.

b) Kilala: This literally means 'womanhood'. Its counterpart is 'kighothi' as used for males. However, this has more amelioration than tumbatu and is used to refer to old women's genitals. It symbolizes respect of a woman whose fecundity is acclaimed.

c) Kitala: This is a term that is also used in the same sense as the male genital.

d) Tuhu: This is also used in the same sense as for men.

e) Tatu: This means 'three' and is used to refer to a girl genital. It connotes oddness of the organ and hence it is being hidden away from anyone's view. In fact a young girl is covered / clothed more care-freely and they occasionally walk naked in public to nobody's dismay.

f) Ikuru: This literally means 'chicken shit' and is used to help young girls see their 
genital as a thing not to pay much attention to.

3.1.3 Itako: is a dysphemism that literally means 'buttocks'. This is mildly viewed as taboo word but it is no quite rude or impolite to use it to refer to buttocks. It has the following substitutes:

a) Nyuma: This literally means 'behind' and is used as a location term to refer to buttocks. However, this has some degree of pejoration.

b) Kichumbi: Literally meaning 'sitting stool', this is used to refer to either an old and respectable woman's buttocks but the speaker wants to be polite and respectful.

c) Makalio: This term is borrowed from Kiswahili (also a euphemism in that language) and it is used is seen by many in the speech community as the most ameliorative label. It is used to refer to buttocks of all people of both sexes and all ages.

d) Mahatama: The literal meaning could not be established but it is a coinage to refer to ladies with big buttocks or those that tend to sway their buttocks while walking.

\subsection{Referring to Excretory and Sexual Processes}

Taboo words referring to excretory and sexual processes and their euphemisms are described below.

3.2.1 Kunya: Literally means 'to shit' and its use is tolerated when referring to a child's or animal's excretory process. When used to refer to the same process but by an adult it is seen as disrespectful and impolite. However, its use has been broadened to mean paying a price or taking up a responsibility for an imprudent choice; e.g. enenya na mundu wakwe (i.e. literally 'he/she will shit with that his/her person', meaning he/she will have to bear with the choice she/he made of that person.

There are a number of euphemisms used to refer to excretory process.

(a) Kubaja Mrisha: Literally meaning 'to break the pastoralist', this is used to refer to a need for long call in a setting where no formal latrine is available, notably in social gathering that involves out-of-home setting like village meeting, funeral setting. Occasionally, it is used when one opts for out-of- toilet venue for a long call because of disfavouring the toilet or when there are many people needing to use it and the need to go is urgent.

(b) Kutonga haja: This is the most favoured expression when describing going to a toilet for a long call. Unlike in kubaja mrisha, this term is used when the process involves formal toilet. It is also used when a mature or elderly person, due to medical condition, defecates in bed or with his/her clothes/pants on.

(c) Kuoja kitashira: Literally means 'to empty bowel', it is used in a jovial or amusing interactions among age mates or among folks. It does not matter if the process took place in the formal toilet or a jungle or farm. It can also be used in referring to a person claimed to be respectable but the attitude of the people (or a section of the people) he 
leads or supposedly commands respect of is negative. They use that in a gossipy manner when they happen to witness him/her going to or coming from toilet. We should note that in rural homes in Chasu speaking communities entering a toilet shade/hut only translates to attending long call of nature. Short calls usually take place outside the toilet.

d) Kutonga ldhungo: This literally means 'going to the bush' and it is popular way to refer to going to toilet. In other words, attending long call is referred to as the location it is supposed to happen (i.e. in secluded hideout) rather than the actual process itself, similar to English "going to toilet".

3.2.2 Kukwedhua: This means urinating: Although not so much of impolite to use this expression, it is usually avoided because it also refers to a sexual process of ejaculating. Due to that fact, the Chasu speakers avoid the term especially when referring to adult urination.

Below are substitutes for 'kukwedhua':

a) kugera madhi: This literally means "to put water (into something)" and is used in the sense that water that escapes human body is directed to the ground, which consequently gets 'watered. It thus points to wetting the ground in a manner suggestive of 'doing good' to the soil. Some of the respondents clued that the usage connotes out -of-toilet environment.

Where urinating is/was normally employed and that 'water' and 'watering' is used to refer to urine and urinating to avoid the imaging of sperms and ejaculation. Additionally, peeing onto dry ground was avoidance of mingling urines of different people which was considered to bring bad luck resulting from other people's waste water (bodily fluids).

b) Kupipia: This has no semantic content, just like tussling. It is used for children whose urinating process is believed to be 'pure' since no other process can be discharged using their genital. It is also used in referring to an adult or elderly when, due to some medical condition, pee in bed or in their paints.

c) Kutunda mdhighi: Literally meaning 'to pick medicine' from a tree or shrub, this is a generic term for urinating but most particularly as an announcement by a public worker to social gatherers or travellers with regard to time for or venue of attending to a short call. It is also used when on is in urgent need to urinate but needs to loudly ask for allowance to be made to him to do so.

3.2.3 Kudenga, this taboo word means to have sexual intercourse. This is the most avoided term and it is only heard among the youths whose sociolect is characterized with unrefined speech.

The following are words to substitute the word:

(a) Kugera/kugerwa: Literally it meaning "to put" (for kugera) it is used active form to refer to a man doing the act whereas for a woman it is passivized kugerwa (i.e. 
'to be put into'). The term connotes sex as insertion and which also collocates with kipunde (a male sex organ) whole projection is shafted outward. So, in this euphemism a man 'enters' into a woman and she is entered into or receives the entrance.

(b) Kutunga/kutungwa: This literally means 'to plunge' for males and kutungwa (i.e. to be plunged into') for females. It also communicates sex as forceful insertion where it is a man- willed business-like act and hence no need for woman's consent. It was used in the traditional sense of a man taking charge of the act and not bothering about a woman's consent or feeling in the act.

c) Kuoja Ikongoti. This literally means 'to wash a maize cob' and is a slang by a man (mainly youth) when referring to having a casual sex with a woman. It is like communicating 'quenching thirsty' by use of 'washing' or 'wetting' their maize cob (or their kipunde -penis).

d) Kula mbunze: Literally "to eat honey of small bees" the term is again slang by men referring to an act of making love to a lady whom they find extremely attractive but difficult to woe.

The other terms that are used but communicating mutuality in the act are:

(e) Kuyaana: Literally meaning 'spending a night together', the term which communicates the mutuality and reciprocity in the act.

(f) Kuingana: Literally meaning "to give to each other", this also communicates mutual giving between partners but also adds a value to the act as a precious gift. However, it is the lady who really gives, and so she can say namuinga ('I have given him') and a man receives, so he can say naingwa ('I have been given').

(f) Kufulana: This literally means 'to undress each other' and it communicates the nature of the act that it involves uncovering and so exposing each other's most clothed part of the body. It is as if what transpires after undressing is taken as common-sense consequence.

(g) Kughavia: Literally this means 'to give a share'. This is mainly a phrase used by ladies in referring to act of sex when they say they have shared themselves with someone (a man). A man will talk about kughaviwa (i.e. to be a beneficiary of a shared self by someone else (a lady).

\subsection{Referring to Diseases and Deaths}

Taboo words referring to diseases and their euphemisms are as follows:

3.3.1 Ukimwi:-This is a term borrowed from Kiswahili and it refers to HIV/AIDS. Being a disease the cause of which is largely sexual act (a taboo word) and lacking cure the disease was never given a proper w0rd of its own. As a way out, there are other words substituting this label, follows: 
a) Ihumba: This literally means 'a bad, ugly illness', which is a strategy of pejorativising the disease to create sense of disgust and detest to for it. Unfortunately, its use in referring to a HIV positive person is also a linguistic stigmatizing term.

b) Ivwaji: Literally this means 'a big illness', though it does not denote its lack of cure. This also pejorating the illness but the severity is less than Ihumba.

c) kalunzoa: This literary means 'a small feather' this puts the disease in its functional role of destroying one's body and make them as small and light as a small feather.

d) Kantha: This is a borrowed and adapted from Kiswahili 'kansa' (which was also borrowed from English 'cancer'. The terms for AIDS Ihumba and Ivwaji are also used to refer to this disease.

What is worth noting here is the fact that taboo wards for diseases exist by virtue of their lack of strongly agreed (as per cultural norms) causal factor and lack of cure or a belief that its mere explicit mention would render medicinal initiatives unsuccessful.

\subsection{Referring to Pregnancy, Births and Deaths}

There also socio-cultural activities or biological processes related to pregnancy, and deaths the terms of which gets avoided and, subsequently, substitute words were used, as described below.

\subsubsection{Mda (i.e. pregnancy)}

Among traditional Chasu speakers, there is fear that referring to pregnancy as ' $m d a$ ' could bring bad luck including pregnancy disappearance or miscarriage, malformation of the foetus resulting in physical and / or sensory impairment. As a way out, the Chasu speaking people have the following euphemisms for pregnancy.

a) Kukwea kiete: literally meaning 'climbing up to the market', this is a common expression used for a pregnant woman. The term communicates 'going to the market' for children to deduce to buy something (which in this context, a baby). However, to the adults it refers to a woman gaining 'worth' or 'value' in the eyes of the husband, clan or even the whole neighbourhood, and thus avoiding the shame of childlessness.

b) Kuketa ndeni: this denotes 'to have a womb' and it thus communicates the physique of a pregnant woman which includes a burgeoning stomach. This is also common but mostly among adults.

3.4.2 Kumogha, literally meaning to 'produce', this is seen as too direct and thus impolite. Instead, one of these terms is used.

a) kughenjwa: The word literally means 'to be helped' where God (or ancestors) has His mercy and power or the ancestors' acknowledged for safe delivery of a 
baby. It also acknowledges child bearing as a risk process to the mother's life.

b) Kuvona kajana: literally meaning "to see the baby", this communicates double message. To the children, the mother's journey to the market (crf. kukwea kiete) has eventually been fruitful. To the adults it is a celebrative and victorious acclamation of witnessing a new life first by the mother and then all others.

c) Kuzora kajana: Literally 'to buy a baby', the term has a universal meaning as in kuvona kajana (in the sense meant for children). For the adults, however, it communicates a price paid by the mother of pangs of birth and all its messinessbefore a child can be born safely.

d) Kutheja injini: a rather derogatory term, borrowed from Kiswahili slang kushusha injini ('to bring down an engine'), this is a slang inclined more towards dysphemism than euphemism as it sees pregnancy as a problem and childbearing as a solution to the problem. It also refers to a baby as a thing rather than precious life.

3.4.3 Kufwa: This literally means 'to die' and it is avoided for fear it might hear the speaker and claim yet another victim. The following are its substitutes:

a) Kutonga; literally meaning 'leaving; to indicate one's departure from the mortal world to join the other world. This indicates no hope of returning.

b) Kuzoka: literally 'traveling' - indicating one's sprit leaving the body to embark on a journey to spiritual or ancestral world. In kuzoka, however, a possibility is created of the dead's man's occasional return. This is notably so in referring to respected elderly people or parents when they die.

c) Kuthua vughai: meaning refusing to eat 'ugali', this is a euphemism but with amusing overtones referring to death as a choice and, in this case, not to participate in eating foodstuffs.

d) Kuthamba: Meaning 'to kick' this is more a dysphemism than euphemism as it is used to refer to a death of someone who is disliked by people.

3.4.4 Kujika i.e 'burying', this is also a strategy of avoidance for belief that burying someone is a venerable act and a dead body is held with fear and awe. The following are the substitutes for 'kujika':

a) Kuvika: literally meaning 'to put', this is indicative of respectful preservation of the body. This also indicates a sense of continuity between the dead person and the mortals (who are the relatives). This continuity is in the form periodic visits to the grave or occasional memorial services or casual evocation of the dead person's name to cherish their memories.

b) Kushiia: literally this means 'to earthen' or 'cover with soil' it has dysphemistic connotations. It is used for burial of someone whose life was not viewed as exemplary or virtuous while she/he was alive. Alternatively, it is used to refer to 
burial of someone who was virtuous by his/her enemies.

\section{Conclusions}

The study has proved that Chasu speaking people have rich diversity in their use of euphemisms to avoid unpleasant and impolite words. Such richness is seen both in the number of speech situations and events or circumstances where euphemisms are employed and in the number of euphemisms per one referent. This explains how linguistically crafty Chasu speakers are in their use of euphemisms. Their craftiness is noted in their semantic broadening of the common words to serve the new meaning that substitutes a taboo word. A few were, however, borrowings from Kiswahili, examples being tatu ('three') in referring to female genital, nyuma ('behind' to refer to buttocks, and kantha to refer to cancer.

Another observation is that some of euphemisms are in form of clausal or sentential level rather than being single lexemes. This implies that in the tendency to apply euphemism to abide to the rule of politeness, linguistic indirectness is exploited which, by its nature, allows for verbosity. However, the form of indirectness used to create the euphemisms did not result in obscurity of meaning; rather it resulted in picturesque mental images of what was being communicated.

Lastly, some euphemisms have attitudinal overtones depending on where the person in reference was defined positively or negatively by the subgroup or person using the euphemistic expression. When that was the case the kind of semantic broadening that was involved was either amelioration e.g. kutonga ('to go') as used to refer to death, or kuvika ('to put') as used to refer to burying, on the one hand, or pejoration e.g. kuthamba ('to kick') as used in referring to death, or kushiia ('to earthen') to refer to burial.

\section{References}

Cain, D. (2000). Language Use and Sexual Communication among Xhosa Speakers in Cape Town, South Africa. Unpublished Masters Thesis in Public Health, University of Connecticut.

Cain, D. (2007). Language Use and Sexual Communication among Xhosa Speakers in Cape Town, South Africa. Unpublished M.A.Thesis, University of Connecticut.

Chabata, E., \& Mavhu, W. M. (2005). To Call or Not to Call a Spade a Spade: The Dilemma of Treating 'Offensive' Terms in 'Duramazwi Guru reChiShona 'Lexikos15 AFRILEX-reeks/series 15: 253-264.

Facuade, G., Gbenja, F., Ngozi, K., Ikechukweu, N., \& Nwosu, F. (n.d.). Linguistic Taboos In The Igbo Society: A Sociolinguistic Investigation. [Online] Available: www.language-and-society.org/journal/2-2/6_fakuade_article.pdf (May 13, 2017)

Fernandez, E. C. (2014). Euphemism and political discourse in the British Regional press. Brno Studies in English, 40(1), 5-26. https://doi.org/10.5817/BSE2014-1-1

Galal, M. M. (2014). Death Metaphor in English and Arabic: A Conceptual Metaphorization Approach. International Journal of Linguistics, 6(1), $153 \mathrm{ff}$. https://doi.org/10.5296/ijl.v6i1.4514 


\section{Macrothink}

Greene, C. T. (2000) The Use of Euphemisms and Taboo Terms by Young Speakers of Russian and English. Unpublished M.A. Thesis, University of Alberta.

Hojati, A. (2012). Study of Euphemisms in the Context of English-speaking Media. International Journal of Linguistics, 4(4), 552-562. https://doi.org/10.5296/ijl.v4i4.2933

Lubinga, E., \& Carel, C. (2011). 'No 'til we know.' Fela ba a tseba naa?1 Using African Languages to Communicate about HIV and AIDS to young South Africans. Communicatio, 37(3), 466-481. https://doi.org/10.1080/02500167.2011.589394

Mbaya, M. (2002). Linguistic Taboo in African Marriage Context: A Study of the Oromo 'Laguu'. Nordic Journal of African Studies, 11(2), 224-235.

Musfiroh, U. N. (2014). A Study of Euphemism Used by President Barack Obama In The First Inaugural Address. Unpublished Doctoral Thesis, University of Brawijaya.

Ndlovu, L. (2011). Taboo words, Euphemisms and Language change: An analysis of how taboo words and euphemisms on death and Sexuality Affects the meanings of various words in Ndebele Language. New York: LAP LAMBERT Academic Publishing.

Nyakoe, D. G., Matu, P. M., \& Ongarora, D. O. (2012). Conceptualization of 'Death is a Journey' and 'Death as Rest' in EkeGusii Euphemism. Theory and Practice in Language Studies, 2(7), 1452-1457. https://doi.org/10.4304/tpls.2.7.1452-1457

Oyeka, C. N. (2015) Euphemisms as Substitutes for Verbal Taboos in Igbo Language Dynamics. Ihafa: A Journal of African Studies, 7(1), 117-138.

\section{Copyright Disclaimer}

Copyright reserved by the author(s).

This article is an open-access article distributed under the terms and conditions of the Creative Commons Attribution license (http://creativecommons.org/licenses/by/3.0/). 